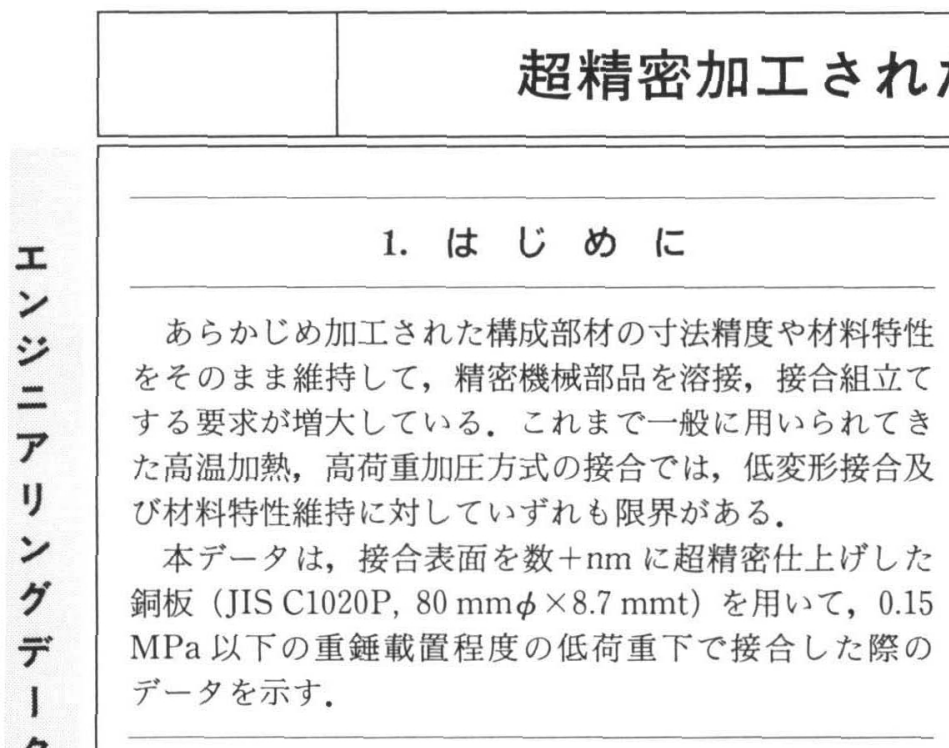

\section{2. 接合法の概要}

銅板の表面を超精密旋盤を用いて，表面粗さ Ry20 $\mathrm{nm}$, 平坦度 $0.3 \mu \mathrm{m} / 80 \mathrm{~mm} \phi に$ 仕上げたあと, 接合温度

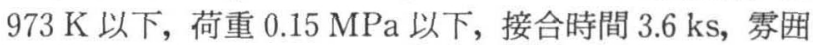
気 $4 \times 10^{-4} \mathrm{~Pa}$ の条件で接合し, すぐれた継手強度を確保 すると共に低変形接合を達成しようとするものである.

表 1 に接合材の超精密加工条件を示す.

\section{表 1 工具と加工条件}

\begin{tabular}{|c|c|c|c|}
\hline 切削工具 & $\begin{array}{l}\text { (1) } \\
\text { (2) } \\
\text { (3) }\end{array}$ & $\begin{array}{l}\text { 材筫: 天然タイャモンド（ } \\
\text { ノース R: } 0.4 \mathrm{~mm} \\
\text { ノース角 : } 90^{\circ}\end{array}$ & 蛙晶) \\
\hline 加工条件 & $\begin{array}{l}1 \\
(2) \\
(3) \\
(4) \\
(5) \\
(5) \\
(7)\end{array}$ & 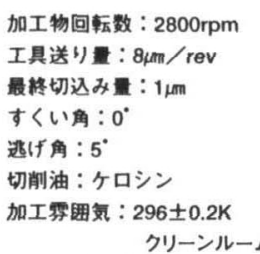 & (クラス 1000) \\
\hline
\end{tabular}

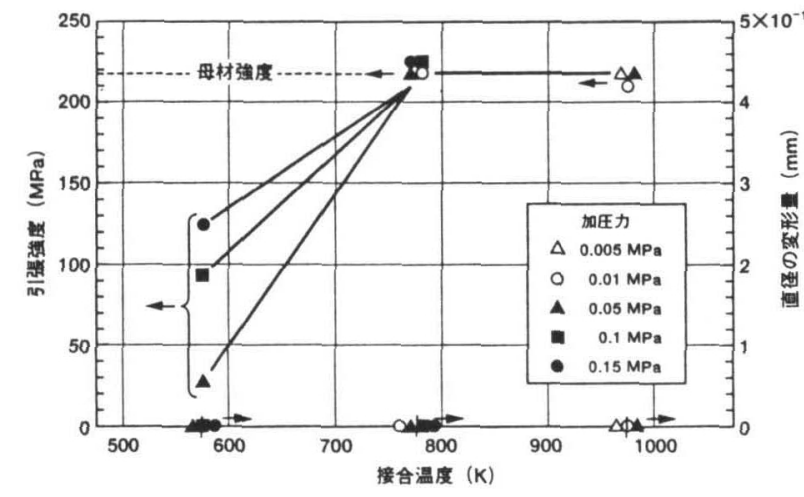

他の援合策件

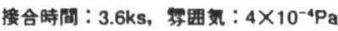

表面粗度：20nm (Ry)，平担度：0.3 $\mathrm{mm} / \phi 80 \mathrm{~mm}$

図 1 継手強度, 変形と接合条件の関係

\section{3. 接 合 結 果}

図 1 に接合条件と継手強度および変形量の関係を示 す. 接合温度 $773 \sim 973 \mathrm{~K}$, 荷重 $0.01 \sim 0.15 \mathrm{MPa}$ (接合温 度 $773 \mathrm{~K}$ ) および $0.005 \sim 0.05 \mathrm{MPa}$ (接合温度 $973 \mathrm{~K}$ ), 接 合時間 $3.6 \mathrm{ks}$, 雾囲気 $4 \times 10^{-4} \mathrm{~Pa}$ の条件で接合すると, 変形が著しく抑制され, 継手強度が母材強度並みとなる 低変形接合が可能である。

上記接合条件のうち, 接合温度 $773 \mathrm{~K}$ および $973 \mathrm{~K}$, 荷重 $0.05 \mathrm{MPa}$ の時のミクロ組織および引張試験片の破 断面，破断状況を図 2 および図 3 に示す。接合温度 973 $\mathrm{K}$ では, 接合界面で結晶粒界の移動が十分に起こり, 破 断が母材中で生じている. また, 接合部はすぐれた気密 性 $\left(<3.6 \times 10^{-12} \mathrm{~Pa} \cdot \mathrm{m}^{3} / \mathrm{s}\right)$ を有する.

\section{参 考 文 献}

1) 深谷他：超精密加工された銅板の拡散接合一銅の拡散接 合に関する研究(第 1 報) -, 溶接学会論文集, 15-3 (1997), $467-475$

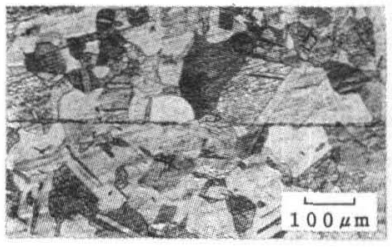

(1)

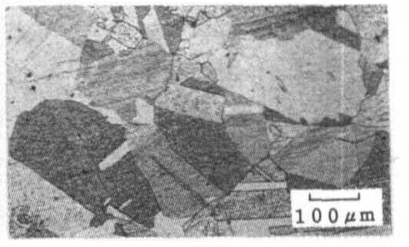

(2) 接合温度 $973 \mathrm{~K}$
他の接合条件

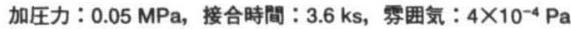
表面粗度 : $20 \mathrm{~nm}$ (Ry), 平担度 : $0.3 \mu \mathrm{m} / \phi 80 \mathrm{~mm}$

図 2 継手部のミクロ組織
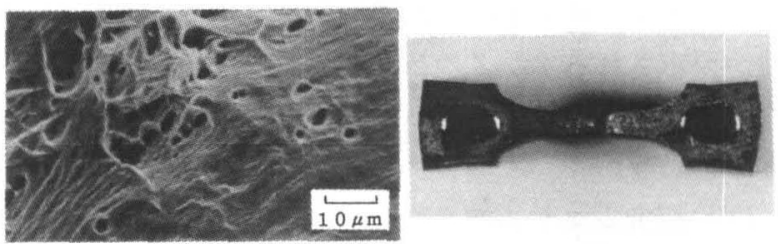

(1) 接合温度

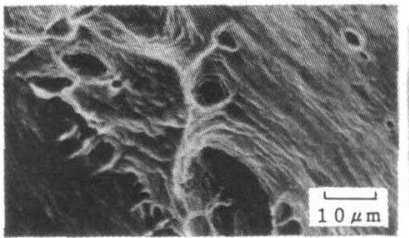

$773 \mathrm{~K}$

(2) 接合温度 $973 \mathrm{~K}$

他の接合条件

加圧力 : $0.05 \mathrm{MPa}$, 接合時間 : $3.6 \mathrm{ks}$, 雲囲気 : $4 \times 10^{-4} \mathrm{~Pa}$ 表面粗度 : $20 \mathrm{~nm}$ (Ry), 平担度 : $0.3 \mu \mathrm{m} / \phi 80 \mathrm{~mm}$

図 3 引張試験片の破断面, 破断状況

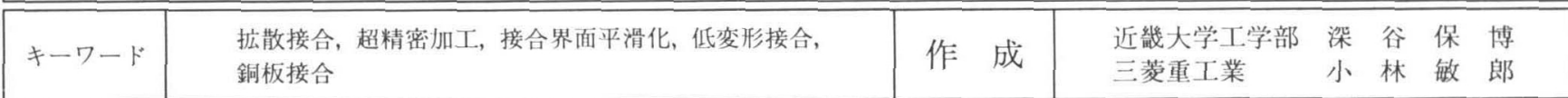

